\title{
Additive and Substitutive Borrowing against Semantic Broadening and Narrowing in the Names of Architectural Structures in Tanzanian Bantu Languages
}

\author{
Amani Lusekelo \\ http://dx.doi./org/10.4314/ujah.v18i1.2
}

\section{Abstract}

The thrust of this paper lies on semantic changes associated with additive and substitutive borrowing in Bantu-speaking communities in Tanzania. Due to contact of languages, semantic differences of the terms related to architectural structures emanate. Apart from data from a few elderly native speakers, research was carried out with the help of undergraduate students of linguistics. Further linguistic materials analysed herein come from dictionaries and lexicons. Although retention of the protoBantu words are apparent, findings indicate that cases of additive borrowing are obvious for new concepts associated with new architectural structures. The additive Swahili names incorporated into Tanzanian Bantu tend to designate specific concepts associated with modern (contemporary) architectural senses such as mulango 'modern door' vs. luigi 'traditional entranceway'. Cases of substitutive borrowing are rare, as demonstrated by the Swahili word dirisha 'window' which replaces chitonono in Chimakonde, echihúru in Runyambo, ilituulo in Kinyakyusa etc.

Keywords: Architectural Terms, Additive Borrowing, Onomastics, Semantic Changes, Substitutive Borrowing, Tanzanian Bantu 


\section{Introduction}

Linguistic issues emanating from contact languages include additive and substitutive borrowing and semantic narrowing and broadening of both loanwords and native words. For Bantu communities, however, cases of substitutive borrowing are rare and in most instances involve semantic narrowing and broadening (Mapunda \& Rosendal 2015). Most of the additive loanwords in Bantu languages of Tanzania come from Kiswahili (Sebonde 2014; Lusekelo 2013; Yoneda 2010) and surround semantic fields associated with 'agriculture and vegetation', 'modern world', 'modern healthcare', 'formal education' (Ibid). This paper aims to articulate penetration of Kiswahili lexis associated with architectural buildings in selected Bantu languages of Tanzania. Scholars in architectural science (e.g. Mwakyusa 2006; Mattsson 2009; Mosha 2011) found that there are old and contemporary architectural structures in individual ethnic groups in African. It is from this assumption that a connection of old and new lexis of Bantu-speaking communities is consummated.

Historicity of the lexis in African societies could not be exaggerated. Nurse (1997) argues that in African societies where most of the information is not written (but passed succinctly through oral channels), comparative examination of words (which are artifacts) yield good results. Nonetheless, narrations related to pottery and iron-smelting appear to be associated with sacredness, rituals and prohibitions (de Maret \& Nsuka 1977; Bostoen 2007). For instance, Bostoen (2007: 178) found that 'in sub-Saharan Africa pottery is invested with great symbolic importance. The craft is surrounded with rituals and prohibitions and several steps in the production sequence serve as a metaphor for interpreting and acting upon certain facets of human experience.' In the theory of semantic change, metaphorization is a common phenomenon 
(Bloomfield 1933; Traugott \& Dasher 2002). Thus, the semantic change of onomastics surrounding old traditional architecture is investigated in this work. The ultimate goal is to demarcate additive borrowing from substitutive ones.

\section{Architecture, Iron-Smelting and Pottery within the Realm of African Past}

The architectural power of African societies is recognized based on the purposes of the houses built within a compound. Mwakyusa (2006) and Mosha (2011) report that in rural settlements in Africa, compounds comprised separate huts, each with a specific purpose in respect to social and cultural values for a family. Shapes of the African huts differed from one society to the other. Three architectural patterns are reported: msonge-structure, tembestructure and banda-structure (Mwakyusa 2006).

Mosha (2011) found that the traditional Sukuma compound composed of ibindo (the main round house) (Figure 1), which is "culturally considered by the local community to be the expression of man's power, worth and leadership capacity to his family and the society around him'. Usually, small ritual huts become part of the Sukuma compound (Mwakyusa 2006). Mattsson (2009, 14) reported that 'old traditional Chagga houses were built in a round formed as a beehive and they have no windows. The houses are made of wood and covered with grass' (see Figure 2). Mwakyusa (2006) has grouped such structures as msonge-type houses found amongst the Chagga (Mount Kilimanjaro area), Haya (Interacustrine area), Nyamwezi and Sukuma (Central Tanzania).

Ten Raa $(1970,132)$ reports that the societies inhabiting central Tanzania have a tembe-type houses which have been originated from the Bantu-speaking communities (Figure 3). Ten Raa (1970) argues that the compounds for Datooga, Iraqw and Maasai appear 
to resemble those of Gogo and Hehe. Amongst the Hehe, Gewald (2005) reported that at Dabaga there was a large two-roomed mud house, for the European inhabitants, and a number of tembe for the native askaris associated with the research station. It is known that a tembe is a flat-roofed house, such as are built in places where thatching and poles suitable for thatching are not obtainable (Ibid). Mwakyusa (2006) found the tembe-type of buildings to be scattered amongst the Gogo and Hehe (Central Tanzania).

The other communities practiced banda structures (Figure 4). Mwakyusa (2006), in his presentations of numerous housing styles of the ethnic groups in Tanzania, found that banda houses are found amongst the Zaramo and Kwere along the Coastline and Nyakyusa in Lake Corridor area.

Most African houses were thatched with green (and/or dry) grass. Nizarudin et al. $(2011,3)$ report that 'the green roofs helped in protecting the building against climatic condition [...] the green roofs offered a good protection against heat and humidity or in short was an effective climate modulator.' It is reported further that 'there were some examples of grass roofs found in Tanzania, which were the Hehe house, the Mbulu house and the Gogo house.' (Ibid, 3). The Sukuma and Chagga houses above substantiate this claim because their roofs are made of thatch grass. This paper investigates the lexis of Tanzanian Bantu languages because the African past can be learned through comparison of lexical elements which occur across languages. Nurse (1997) argues that lexicostatistics favour a proper establishment of the relatedness of the African languages. Such relatedness is found in the terms associated with the making or creation of pottery artifacts. Bostoen $(2007,182)$ postulates the presence of the terms mata and bvmba for 'to make pottery' in Lake Corridor languages ((Nurse 1988; Walsh \& Swilla 2000; Lusekelo 2014) and 
Interacustrine languages (Nurse \& Muzale 1999) respectively. However, some of the languages have adjusted the meaning of the former to include 'to fill in cracks' in Nyakyusa (Tanzania/Malawi), 'to plaster' in Nyiha (Tanzania/Zambia) and 'to build' in Luba (DRC).

Another case which is used to describe interrelatedness of the African history involves iron-smelting. Blench (2006, 32) suggests that 'much the same is true of iron-working. Iron-working seems to develop first in sub-Saharan Africa in the middle of the first millennium BC, based on Taruga in Central Nigeria with rather earlier dates in the Sahara'. Though its direct implication to relatedness is limited (Ibid), iron-working has some terminologies which are found across Sub-Saharan Africa. De Maret and Nsuka $(1977,47)$ mention the proto-Bantu *geda 'iron' with reflexes such as élá 'iron' and gera 'needle, pin, puncheon, barrel of tin'. Two other important words associated with iron-working in Bantuspeaking areas are *yúma whose reflexes include the semantics of 'wealth', 'valuable things' and 'goods' (Ibid, 48) and *cúd whose reflexes mean 'to forge' and/or 'black-smith' (Ibid, 49).

\section{The Theory of Semantic Narrowing and Broadening in the Realm of Lexical Borrowing}

According to the divisions suggested by Bloomfield (1933), the theory of semantic changes has numerous sub-branches, namely additive and substitutive loanwords and semantic broadening, narrowing and shift (Akidah 2013; Mapunda \& Rosendal 2015). Within the theory, semantic broadening and narrowing capture facts related to changes of meanings of foreign words incorporated into a target language. On the one hand, some borrowed lexical items undergo semantic widening (expansion) in the sense that their meanings capture more information in the target language 
than was the case in the source language. Akidah $(2013,10)$ uses the Kiswahili word hati (of Arabic origin) which initially meant 'handwriting, script, line' but today it means 'handwriting, script' and 'document'. Other borrowed words undergo semantic shift in that their former meanings change when they get incorporated in the target language, e.g. Kiswahili noun tajiri changed from 'businessman, merchant' to 'rich person' (Akidah 2013, 11). Since recent studies (e.g. Akidah 2013; Lusekelo 2013; Mapunda \& Rosendal 2015) found that Swahili words undergo semantic broadening and narrowing once they are incorporated in Bantu languages of Tanzania, an examination of loanwords for architectural terms appears to be a welcome contribution to make.

With regard to borrowing, inventions of new concepts, ideas, objects and artifacts in donor languages lead to formulations of new nouns for such concepts, ideas, objects and artifacts in target languages (Haspelmath 2009; Lusekelo forthcoming).

Haspelmath $(2009,37)$ argues that 'loanwords are always words (i.e. lexemes) in the narrow sense, not lexical phrases, and they are normally unanalyzable units in the recipient language.' When such new nouns are transferred from donor languages to target languages, they may become additive or substitutive. Lusekelo (forthcoming) argues that additive loanwords relate to lexical words which capture new information in the target language while substitutive loanwords do tend to replace the existing words in a receiving language. The former loans penetrate into receiving languages without affecting negatively the existing lexicons while the later tend to push away some lexical entries in the target language. Additive borrowing tends to be used to cover new concepts in the modern world, e.g. mutuka 'motorcar' and simu 'telephone' in Ngoni which were borrowed from Kiswahili words motokaa and simu (Mapunda \& Rosendal 2015, 188). 
Substitutive loans tend to replace native words, e.g. the word nywele 'hair' from Kiswahili has replaced three specialized words for hair in Ngoni: nywili 'all kinds of hair', majunju 'long and uncared for hair' and mayela 'pubic hair' (Ibid, 186). Since Mapunda and Rosendal (2015) found that additive borrowing is more common than substitutive borrowing in many languages of the world, this investigation wants to find out the amount of additive and substitutive borrowing for architectural terms.

\section{The data for this research}

In almost all architectural structures, nine (9) common terms might be apparent for similar parts-of-house, namely the roof (thatched or plastered by mud), pillar (the central pole, mainly vertical one and/or horizontal), the door and door frames (doorpost, vertical and horizontal) and house floor (plastered by mud or animal dung). The words fire and fireplace (located inside the house) are discussed in conjunction. The discussion about the semantics of individual names yields potential information about retention and expansion of nomenclature due to contacts of Bantu communities. Notice at this juncture that the word window is given special attention because it is reported that old traditional houses did not have windows (Mattson 2009). Lastly, the variations of names for the word loft (attic or ceiling board) are discussed at the end of this section.

The survey of the above names begins with dictionaries for Bantu languages of Tanzania (sources: Rugemalira 2013, 2009, 2002; Botne 2008; Kahigi 2008; Mdee 2008; Mreta 208; Rubanza 2008; Sewangi 2008; Mwalonya et al. 2004; TUKI 2001; Felberg 1996). Apart from data gathered from Bantu dictionaries, native speakers of Kisukuma, Kizanaki, Kihehe, Kimeru, Kinyaturu and Kigogo contributed the linguistic materials examined in this 
paper. ${ }^{1}$ The focus of the analysis lies on the semantics of the Swahili loanwords into Tanzanian Bantu. The intent, as said, is to evaluate the semantic changes of such borrowed words as they manifest in target languages.

\section{Findings}

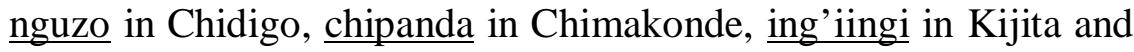
enyómyo in Runyambo: Additive and Substitutive Borrowing vs. Semantic Narrowing and Broadening

Probably an analysis of the data on the name ROOF should begin. Table 1 has data which substantiate that Bantu huts have had roofs. In fact, Nizarudin et al. (2011) reported the utilization of green (thatched) roofs in the area. The pervasiveness of different names in the lexicons substantiate this claim, e.g. -sara in Kiikizo and Chiruuri, oluswi in Luzinza and Kijita etc.

$\begin{array}{lllcc}\text { Language } & \text { Zone } & \text { Terms } & \text { English Gloss } & \text { Alternative Meanings } \\ \text { Kikahe } & \text { E64 } & \text { mwalo } & \text { roof } & \text {--- } \\ \text { Digo } & \text { E73 } & \text { chombo } & \text { one side of a roof } & \text {--- } \\ \text { Nyamwezi } & \text { F22 } & \text { nzelele } & \text { roof } & \text {--- } \\ \text { Gogo } & \text { G11 } & \text { itembe } & \text { roof } & \text { ihapa } \\ & & & & \text { 'rafter' }\end{array}$

${ }^{1}$ For the data analysed in this paper, I am grateful to the native speakers of the numerous Bantu languages who volunteered to offer the linguistic materials. Specifically, I am grateful to undergraduate students at Dar es Salaam University College of Education and Graduate students of linguistics at Ruaha Catholic University and University of Dar es Salaam. 


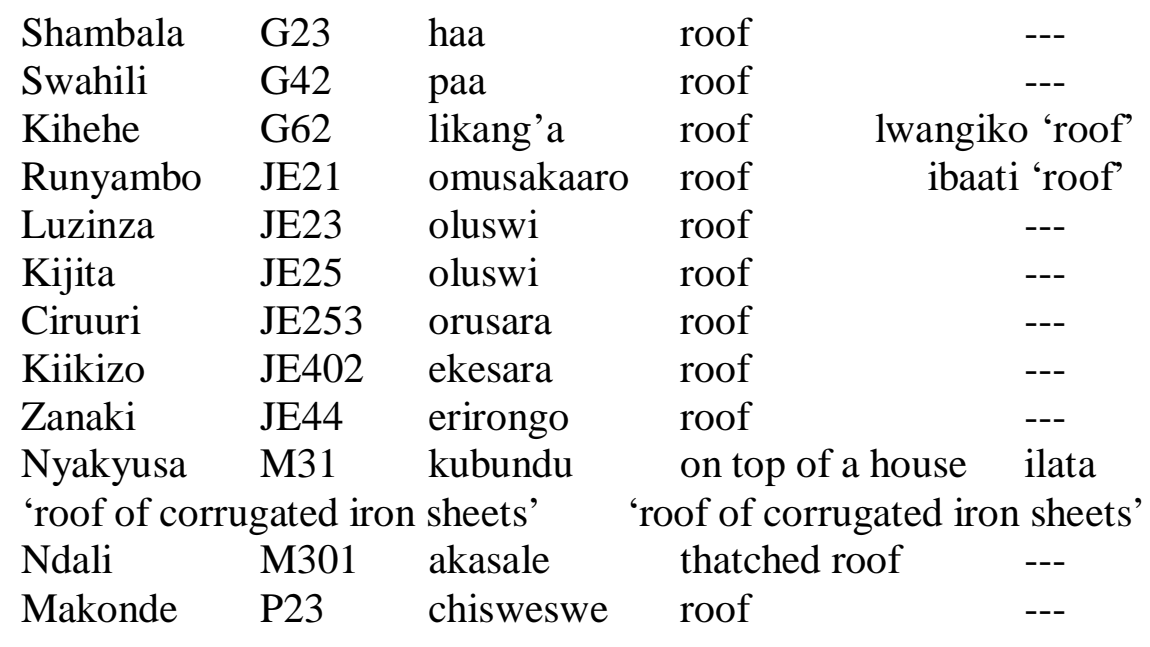

Table 1: Names of the ROOF in selected Bantu languages of Tanzania

Perhaps a fascinating issue is associated with the borrowing of the term ibaati for the roof made of corrugated iron sheets in Runyambo. Nyakyusa and Ndali speakers have adjusted the essence of the word ilata for the roof made of corrugated iron sheets. Based on scholars on architecture science (Mattson 2009; Mwakyusa 2006), it is plausible to argue here that the borrowing associated with corrugated iron sheets is additive in nature because it introduces notion which was not traditionally available in Bantuspeaking communities. Mapunda and Rosendal (2015) and Lusekelo (2013) found that additive borrowing becomes common in case new concepts are introduced in Bantu communities.

Comparative data for the pillar (central post) yield interesting facts. Perhaps we should begin with observations of data in Table 2 below. 


\begin{tabular}{|c|c|c|c|}
\hline Language & Zone & Terms & English Gloss \\
\hline Kikahe & E64 & kidi & pillar \\
\hline Digo & E73 & $\begin{array}{l}\text { nguzo } \\
\text { boriti }\end{array}$ & $\begin{array}{l}\text { pillar, } \\
\text { main pole supporting the roof }\end{array}$ \\
\hline Sukuma & F21 & ng'hingi & pillar \\
\hline Nyamwezi & F22 & lusingi & pillar \\
\hline Gogo & G11 & ihapa & beam that supports the roof \\
\hline Shambala & $\mathrm{G} 23$ & nguzo & pillar \\
\hline Swahili & G42 & nguzo & pillar \\
\hline Kihehe & G62 & mgamba & pillar \\
\hline Runyambo & JE21 & enyómyo & pillar \\
\hline Luzinza & JE23 & $\begin{array}{l}\text { enyomyo } \\
\text { enchinji }\end{array}$ & $\begin{array}{l}\text { house post } \\
\text { pillar }\end{array}$ \\
\hline Kijita & JE25 & ing'iingi & pillar \\
\hline Ciruuri & JE253 & ing'iingi & pillar \\
\hline Kiikizo & JE402 & ekesara & pole, roof \\
\hline Kisimbiti & JE431 & intímo & pillar \\
\hline Zanaki & JE44 & erimu & pillar \\
\hline Ndali & M301 & amaseengo & --- \\
\hline Makonde & $\mathrm{P} 23$ & chipanda & pillar \\
\hline
\end{tabular}

Table 2: Names of the PILLAR (central pole) in selected Bantu languages of Tanzania

Basically two observations become apparent from the data in Table 2 above. Firstly, manifestation of this structure is robust in the data. The terminologies -panda and -banda are attested in Makonde and Nyakyusa respectively. In Interacustrine languages, the Bantu words -nyomyo and -ng'iingi are found. Notice some semantic narrowing attested for the later word: the Nyakyusa speakers have the word -kiingi for the pole used in the kraal while 
the Ndali speakers have -kiingi for the leader of a dance (Felberg 1996; Botne 2008). Perhaps the theory of semantic broadening and narrowing allows a proper analysis of the data (section 4.2). It will be presented that the meaning of -ng'iingi or lusingi 'pillar' is transferred to another function, namely "pole to tie animals" in Nyakyusa.

Secondly, in relation to pillar, Swahili loanwords for pole are attested: omulongoti $[<$ mlingoti $]$ for Luzinza, bilito $[<f i t o]$ in Kihehe and senkénge [<senyenge] in Kisimbiti. Nonetheless, these words have been borrowed for the purpose of referring to 'poles as building materials' rather than a built pillar that becomes a central one mainly in the traditional msonge (but also in tembe and banda houses). Perhaps the building materials have been altered by the use of eucalyptus poles [milingoti in Swahili] instead of bamboo trees which were traditionally used (Moshi 2011; Mattson 2009; Mwakyusa 2006).

The names for the word 'door' in Tanzanian Bantu languages are given in Table 3 below. The main fascinating issue is the pervasiveness of the words mulango which appear to have come from Swahili and luigi, which seems to be a native one. As far as contact linguistics is concerned, the word mulango appears to be an innovation, which is associated with the modern door, with shutters. In the literature for architecture (Mattson 2009; Mwakyusa 2006), old traditional huts in Bantu-speaking communities appear to lack door-shutters thus, the entrance was treated as an opening (doorway, entranceway), instead of a door with shutters. Based on semantic broadening and narrowing, there is specialization of terms. On the one hand, it is plausible to argue here that the word mulango is specifically used to designate a door with shutters in Bantu-speaking communities of Tanzania. Thus, this is an additive loanword whose meaning fills the gap of modern 
door. On the other hand, the native word luigi or ruige in Chiruuri, Luzinza, Nyakyusa and Ndali has a referent to entranceway or a passage for getting into a traditional hut. This is a typical semantic narrowing case. The word luigi or ruige is pervasive because morphophonological similarities manifest in names such as lwidi in Makonde, luvwi in Chidigo, luzizi in Chigogo and $u v i$ in Shambala. This word has undergone semantic narrowing in the sense that it refers to an old traditional door. Despite the variations, the word has undergone semantic narrowing across Tanzanian Bantu.

$\begin{array}{llll}\text { Language } & \text { Zone } & \text { Terms } & \begin{array}{l}\text { English Gloss } \\ \text { door }\end{array} \\ \text { Kikahe } & \text { E64 } & \text { mongo } & \text { door, shutter } \\ \text { Digo } & \text { E73 } & \text { luvwi } & \text { door } \\ \text { Sukuma } & \text { F21 } & \text { lwigi } & \text { door } \\ \text { Nyamwezi } & \text { F22 } & \text { mzigo } & \text { door } \\ \text { Gogo } & \text { G11 } & \text { luzizi } & \text { door } \\ \text { Shambala } & \text { G23 } & \text { uvi } & \text { door } \\ \text { Swahili } & \text { G42 } & \text { mlango } & \text { door } \\ \text { Kihehe } & \text { G62 } & \text { mlyango } & \text { door } \\ \text { Runyambo } & \text { JE21 } & \text { omuryângo } & \text { door } \\ \text { Luzinza } & \text { JE23 } & \text { lwigi } & \text { door } \\ \text { Kijita } & \text { JE25 } & \text { mulyaango } & \text { door } \\ \text { Ciruuri } & \text { JE253 } & \text { orwiigi } & \text { door } \\ \text { Kiikizo } & \text { JE402 } & \text { uruige } & \text { door } \\ \text { Kisimbiti } & \text { JE431 } & \text { ekesáku } & \text { door } \\ \text { Zanaki } & \text { JE44 } & \text { ekiseku } & \text { door } \\ \text { Ndali } & \text { M301 } & \text { ichiigi } & \text { door } \\ \text { Makonde } & \text { P23 } & \text { lwidi } & \text { door }\end{array}$

Table 3: Names of DOOR in selected Bantu languages of Tanzania 
The other approach to such data surrounds substitutive borrowing in that the Swahili-oriented word, i.e. mlango 'door' is being replacing the native word luigi (or ruigi) 'door' in Digo, Makonde, Chiruuri and Gogo.

Another comparative issue arises with regard to the architectural term 'door post' in the Bantu languages. Firstly, in many societies which built itembe- and msonge-structures (e.g. Chigogo), the doorpost is not part of the traditional vocabulary. Secondly, names in mugámba Runyambo and ing'iingi in Chiruuri yield numerous semantic notations in other Bantu languages, as discussed in the next section.

\begin{tabular}{|c|c|c|c|}
\hline Language & Zone & Terms & English Gloss \\
\hline Digo & E73 & mwimo & doorpost \\
\hline Runyambo & JE21 & omuziringíti & doorpost \\
\hline Ciruuri & JE253 & ing'iingi & doorpost \\
\hline Kiikizo & JE402 & rite & door bar \\
\hline Nyakyusa & M31 & --- & --- \\
\hline Makonde & P23 & lipandago & doorpost \\
\hline
\end{tabular}

Table 4: Names of DOOR BAR or PILLAR across selected Bantu languages of Tanzania

The same sources enlist names of the 'fireplace', as provided in Table 5 below. Scholars in architecture science found that old traditional houses tend to set aside a place specifically designated 
for fireplace (Mosha 2011; Mattsson 2009). Maho (2005) reconstructs the term jíko for 'fireplace'.

\begin{tabular}{|c|c|c|c|}
\hline Language & Zone & Terms & English Gloss \\
\hline Kikahe & E64 & riko & kitchen \\
\hline Digo & E73 & dziko & fireplace, stove \\
\hline Sukuma & $\mathrm{F} 21$ & shikome & fireplace \\
\hline Nyamwezi & F22 & ijiko & kitchen \\
\hline Gogo & G11 & chikozo & fireplace \\
\hline Shambala & G23 & ziko & fireplace \\
\hline Swahili & G42 & jiko & kitchen, fireplace \\
\hline Kihehe & G62 & kikoso & fireplace \\
\hline \multirow[t]{3}{*}{ Runyambo } & JE21 & amahéga & fireplace \\
\hline & & ichumbiro & kitchen \\
\hline & & ijiko & kitchen \\
\hline Luzinza & JE23 & ichumbilo & kitchen \\
\hline Kijita & JE25 & ijiko & kitchen \\
\hline Ciruuri & JE253 & amasiga & fireplace \\
\hline Kiikizo & JE402 & ririko & kitchen \\
\hline Kisimbiti & JE431 & riíko & kitchen \\
\hline Zanaki & JE44 & eririko & fireplace \\
\hline Nyakyusa & M31 & ijhiko & fireplace, kitchen \\
\hline
\end{tabular}

${ }^{2}$ While Guthrie (1967) reconstructed the terms *-dido and *moto for FIRE in proto-Bantu, both proto-forms manifest in the reflexes across Tanzanian Bantu languages. Based on Nurse (1997), the amount of retention in these languages is higher for FIRE. This signifies the importance of FIRE in Bantu-speaking communities. 


\begin{tabular}{|c|c|c|c|}
\hline \multirow{3}{*}{ Ndali } & & pambembelo & fireplace \\
\hline & M301 & ichooto & fireplace \\
\hline & & & kitchen \\
\hline & $\mathrm{P} 23$ & $\begin{array}{l}\text { chiwuli } \\
\text { lijiko }\end{array}$ & $\begin{array}{l}\text { fireplace } \\
\text { kitchen }\end{array}$ \\
\hline
\end{tabular}

Table 5: Names of FIREPLACE in selected Bantu languages of Tanzania

Two observations obtain in the data in Table 5 above. Firstly, in many Bantu languages of Tanzania (e.g. Nyamwezi, Makonde, Ndali, Nyakyusa, Runyambo and Zanaki) the alternative words for fireplace appear to be the word jiko, which is reconstructed to proto-Bantu. However, in most cases the word jiko is used to mean kitchen rather than the traditional fireplace. It is plausible to argue here that the essence of the word jiko emanates from the Swahili word meaning kitchen rather than fireplace, hence a case of additive borrowing.

However, the presence of the alternative words for fireplace in these languages (e.g. shikome in Sukuma, chiwuli in Makonde, ichooto in Ndali, pambembelo in Nyakyusa and amahéga in Runyambo) represent a case of substitutive borrowing. It is argued herein that the word jiko is treated as additive loanword (because it is of Swahili origin incorporated into Bantu languages of Tanzania to entail a separate building for kitchen) but becomes substitutive loanword (because it is incorporated in Tanzanian Bantu languages and replaces native words). Secondly, the word 'fireplace'obtains the labels mafigwa in Chigogo, amahéga in Runyambo and amasiga in Chiruuri. It will be plausible to argue that it is a loanword from Swahili word mafiga 'cooking stone'. Within the realm of the theory of semantic change, it appears that 
semantic expansion is applied. The 'fireplace' and 'cooking stones' are represented by one lexical entry, namely -figa.

The words 'window' and 'floor' demonstrate issues related to consequences of language contact between Swahili speakers and speakers of other Bantu languages in Tanzania (Table 6). Two kinds of terms for window appear to manifest in the data, namely the native words such as igele in Nyamwezi, chitonono in Chimakonde, echihúru in Runyambo and ilituulo in Kinyakyusa which co-exist with the foreign word lidilisha, idirísa and idilisya, respectively. This is a kind of substitutive borrowing in which the former term is being replaced by the Swahili word dirisha. It should be noticed that the traditional label referred to a hole on the whole of a traditional house while the latter represents a window with shutters. In many other Bantu-speaking communities, an additive word dirisha is borrowed from Swahili.

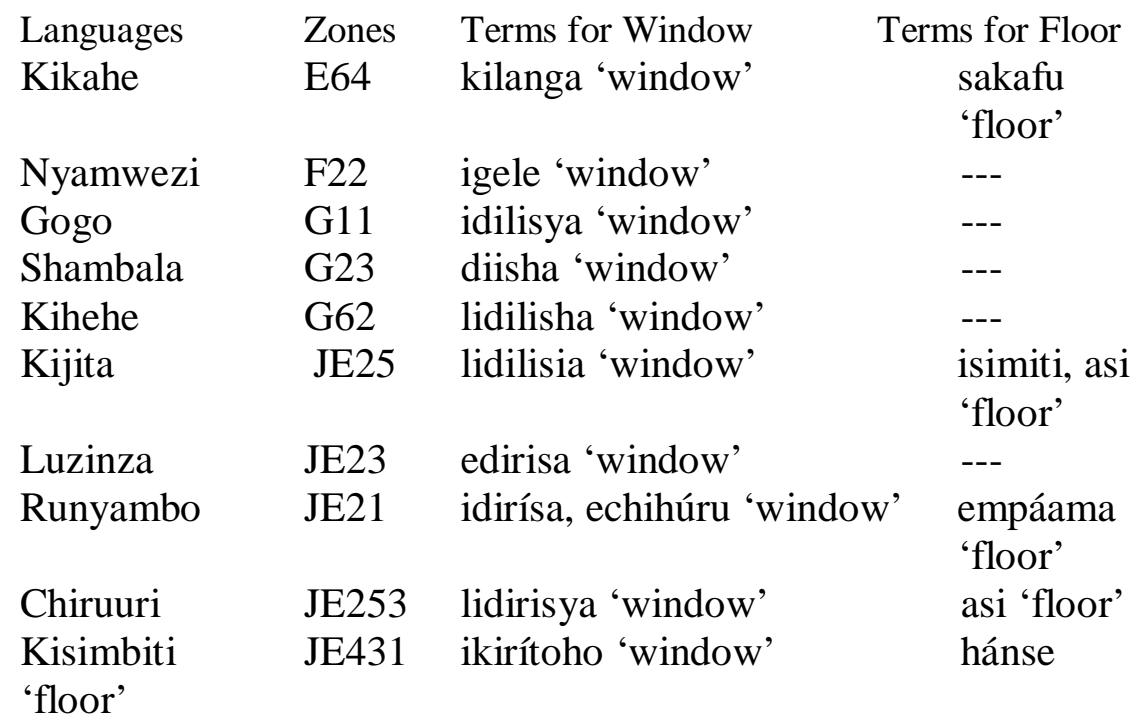


Kinyakyusa M31 ilituulo, idilisya 'window' ikipalo 'floor'

\begin{tabular}{|c|c|c|}
\hline & M301 & amabwiindo 'windows' \\
\hline nde & $\mathrm{P} 23$ & chitonono, lidilisa 'win \\
\hline
\end{tabular}

Table 6: Names for WINDOW and FLOOR in selected Bantu languages of Tanzania

The names for 'floor' substantiate that it had not been part of the architectures in the Bantu-speaking communities. The words asi in Chiruuri or hánse in Kisimbiti refer to the ground in the house rather than a built floor. The Swahili words sakafu in Kikahe and isimiti in Kijita have referents to the Swahili word sakafu and English loanword cement. These terms substantiate that Kiswahili brings additive loans into Bantu languages in Tanzania. Now the paper arrives at the end-part of this section. The word loft (garret, attic or ceiling board) provides the following words across selected Bantu languages.

\begin{tabular}{|c|c|c|c|c|}
\hline Language & Zone & Terms & English Gloss & $\begin{array}{l}\text { Alternative } \\
\text { Meanings }\end{array}$ \\
\hline Sukuma & $\mathrm{F} 21$ & kaano & loft & --- \\
\hline Nyamwezi & F22 & kano & loft & --- \\
\hline Kikahe & E64 & kahi & loft & $\begin{array}{l}\text { mwanya 'on } \\
\text { the loft' }\end{array}$ \\
\hline Digo & E73 & dari & ceiling & --- \\
\hline Shambala & $\mathrm{G} 23$ & taa & loft & --- \\
\hline Swahili & G42 & dari & loft & --- \\
\hline Kihehe & G62 & kigwitu & loft & --- \\
\hline Runyambo & JE21 & edáari & loft & --- \\
\hline Luzinza & JE23 & ilali & loft & --- \\
\hline
\end{tabular}




$\begin{array}{lllll}\text { Kijita } & \text { JE25 } & \text { kumatengejo } & \text { loft } & --- \\ \text { Ciruuri } & \text { JE253 } & \text { libhiindo } & \text { loft } & --- \\ \text { Kisimbiti } & \text { JE431 } & \text { risésemi } & \text { loft } & --- \\ \text { Nyakyusa } & \text { M31 } & \text { ijhulu } & \text { loft } & --- \\ \text { Ndali } & \text { M301 } & \text { ijulu } & \text { loft } & --- \\ \text { Makonde } & \text { P23 } & \text { chitakaha } & \text { loft } & \text { likangala }\end{array}$

Table 7: Names of LOFT in selected Bantu languages of Tanzania

Table 7 has data which divides twice, namely the traditional names such as ijulu in Chindali, libhiindo in Chiruuri and chitakaha in Chimakonde on the one hand and Swahili related term dari such as edáari in Runyambo and ilali in Luzinza. The former represents retention of the old architectural label while the latter signifies substitutive borrowing from coastal Bantu languages such as Swahili and Digo.

\section{Discussions}

In this section, attention is paid to two broad issues. Section 4.1 is devoted to the dispersal of the various names of architectural structures in the Bantu zones of Tanzania, as discussed in Lusekelo (2014). A single term called 'loft' is used as a case study. In section 4.2, another case of the word 'pillar' is used to delineate a boundary between additive and substitutive borrowing as well as semantic broadening and narrowing.

\section{igulu and kano in Lake Corridor vs. dari and kai in Mount Kilimanjaro: Distribution of the Names of Architectural Structures in Tanzania}

Research about Bantu lexis becomes fruitful when words are examined from the knowledge of individual speakers. Bostoen 
(2007) is convinced that research amongst speakers of the presentday Bantu languages yield good indicators of the historical issues in Africa. Prior to this, Nurse (1997) suggested that the history of African can also be learned through the description of linguistic data based on lexicostatistics. It is in this line that the dispersal of terms of architectural structures, which is discussed hereunder, could be gathered from speakers of the selected languages.

A single term i.e. 'loft' is examined for this section. Findings point to groupings obtained on the basis of the housingstyle. The Lake Corridor Bantu make use of the words -kano and gulu, which help to divide the languages into two main clusters. On the one hand, in the Bantu communities in the northern areas of the Lake Corridor (Nurse 1988), specifically in Dodoma, Iringa, Morogoro and Njombe regions (LOT 2009), the word -kano is robust, as in Luguru [G35] mkano, Kihehe [G62] ikano, Bena [G63] kukanu etc. On the other hand, the south-western Lake Corridor languages (in Mbeya, Songwe and Rukwa regions) make use of the words igulu in Nyamwanga [M22], Nyiha [M23], and Safwa [M25] and ijulu for Nyakyusa [M31] and Ndali [M301]. The Lake Corridor Bantu had been said to build old traditional banda-structure (Mwakyusa 2006), which is likely to possess the loft.

Bantu languages in Mount Kilimanjaro area (ranging from Usambara and Pare mountains in Tanga and Kilimanjaro regions to Mount Meru in Arusha region, as per Nurse 1979 and LOT 2009) make use of the word kahi (or kai) for the 'loft', as in Kikahe and Digo respectively (see Table 7 above). In Chasu [G22], Kimeru [E621], Mashami [E621], Kimochi [E622] and Rombo [E623], the word kai is used. Mwakyusa (2006) and Mattson (2009) reported that Chagga, Pare and Meru [E621] speaking communities built msonge-structure, which is likely to set a structure of a loft. 
With regard to the Interacustrine Bantu, division of three clusters is apparent herein (Nurse \& Muzale 1999): Rutara group (Runyambo [JE21], Ruhaya [JE22] and Luzinza [JE23]), Mara languages (Kurya [JE43], Kisimbiti [JE431] and Zanaki [JE44]) and Suguti cluster (Kijita [JE25] and Chiruuri [JE253]). The obtainable names allow clustering. Swahili-oriented terms are used in Rutara languages such as edáari in Runyambo, edali in Ruhaya and ilali in Luzinza. The Mara dialects in eastern Bantu utilize the word rongo/longo such as ilongo in Kuria and erirongo in Zanaki. The Suguti group has different terms, such as libhiindo in Chiruuri and kumatengejo in Kijita. Mwakyusa (2006) reported that clans in these areas built msonge-structure, which perhaps had a loft.

The Central Tanzania societies include Bantu F languages, represented herein by Sukuma [F21], Nyamwezi [F22], Sumbwa [F23], Nilamba [F31] and Nyaturu (or Remi) [F32]. Mwakyusa (2006) found that these societies (Nyamwezi, Nyaturu and Sukuma) built msonge-structure which permitted a loft. Data at hand demonstrates usage of these words: kaano in Nyamwezi, ihafa in Nyaturu and ilumbilo in Sukuma.

\section{ing'hingi in Sukuma vs. kikingi in Nyakyusa vs. kipfanda in Nyaturu vs. mgamba in Kihehe: Semantic Shift of Names of Architectural Structures}

There are issues of semantic shift in the linguistic materials discussed in this paper. The word 'pillar' offers the best option to present such a matter. Its semantics shifted in some Tanzanian Bantu. There are Tanzanian Bantu which use ing'ingi for a pillar, e.g. Chiruuri and Kijita: ing'iingi, Sukuma: ng'hingi and Nyamwezi: lusingi. These words have referent to a vertical central pole in a hut which holds the roof. In Chiruuri, the same word is used to mean 'doorpost'. Such a meaning concerns semantic 
broadening in the sense that the word obtains two referents. In Kijita, semantic broadening is attested for the same word which has referent to 'poles'. The word ikikingi in Nyakyusa has referent to a peg for tethering an animal in a kraal. In Nyaturu [F32], the word $n g$ 'ingi has referent to 'the horizontal central pole that holds the roof of the hut'. This case represents semantic shift in which the same word has referents to different objects. The words for 'pillar' are imbanda in Nyakyusa and kipfanda in Nyaturu.

The same notion is realized as mgamba 'pillar' in Kihehe and mugamba 'pillar' in Nyaturu. However, the Runyambo speakers have the word mugamba for the doorpost and enyómyo for the pillar. Thus, semantic shift is realized by this word which has different referents in Kihehe, Nyaturu and Runyambo.

Such data has implications to the question of cognates in Bantu languages. Nurse (1997) argues that related languages will maintain cognates, though with some phonological differences. The data above does not provide justifications to cognates rather shows semantic changes across languages. Perhaps the metaphorical usage mentioned in Bostoen (2007) could justify the interpretation of data. The change in the referents might be associated with metaphorical use of the words. The data above indicate that though referents changed, the new ones have remained architectural structures.

Bloomfield $(1933,425)$ pointed out that 'in other instances the comparisons of related languages show different meanings of forms which we feel justified in viewing as cognates.' Perhaps the case of PILLAR affirms this theory of semantic changes. Traugott and Dasher $(2002,57)$ found that 'sometimes the root may undergo broadening in one language and narrowing in another.' The changes associated with related artifacts such as building materials in Tanzanian Bantu. In this case, Traugott and Dasher (2002, 57) 
argue that 'almost all cases of narrowing and broadening, pejoration and amelioration are cases of metonymic change: shifts in use dependent on context.'

\section{Conclusions}

It is apparent now that the central gist of this paper had been on semantic changes associated with additive and substitutive borrowing in Bantu-speaking communities in Tanzania. The examination of the nomenclatures of specific architectural terminologies guided the discussion herein. As a way of offering two concluding remarks, issues of borrowing and semantic shift are presented.

Firstly, it is plausible to argue that most Bantu-speaking communities in Tanzania practiced architectural science which is related to msonge, tembe and banda houses. Following Nurse (1997), there is high rate of retention of native terms related to specific structures, namely 'roof', 'pillar' and 'fireplace'. Cases related to other terms provide evidence for additive and substitutive borrowing. Since the Bantu-speaking communities are dynamic, new words have been incorporated in order to accommodate new building structures. This is apparent for the words 'kitchen' (as a separate house), floor and roofs made of corrugated iron sheets. On the one hand, a specific case involves mulango, which is a loanword referring to modern (contemporary) door as opposed to luigi, whose referent is an entry or doorway. As it is the case in many instances, most of the loanwords which come from Swahili (Mapunda \& Rosendal 2015; Sebonde 2014; Lusekelo 2013; Yoneda 2010) represent a typical case of additive borrowing. On the other hand, native words such as chitonono in Chimakonde, echihúru in Runyambo and ilituulo in Kinyakyusa co-occur with foreign words such as lidilisha or eridirisa in almost 
all Bantu-speaking communities. This is a typical case of substitutive borrowing in which the former term is being replaced by the Kiswahili word dirisha.

Secondly, the other linguistic phenomenon discussed herein surrounds distribution of the terms in the various Bantu clusters. It has become apparent that each Bantu community appears to make use of a similar name across the family. This is the case of Rutara languages which make use of dali/dari for loft while Mara dialects use longo/rongo for the same. Likewise, the Lake Corridor languages from Mbeya cluster make use of igulu/ijulu while the Iringa cluster uses kano. Such data represented the retention of the names of architectural structures in communities which practiced banda- and msonge-structures. Nonetheless, such words are associated with semantic shift in some languages. The case of ing'iingi 'pillar' in Kijita and Chiruuri and kikingi 'peg for tethering an animal' in Nyakyusa substantiates. Here two different referents are denoted by the same word. This case is treated as semantic shift across Tanzanian Bantu.

\author{
Amani Lusekelo \\ Department of Languages and \\ Literature \\ University of Dar es Salaam \\ alusekelo@duce.ac.tz
}

\title{
References
}

Akidah, Mohamed A. 2013. Phonological and semantic change in language borrowing: The case of Arabic words borrowed into Kiswahili. International Journal of Education and Research 1(4): 1-20. 
Blench, Roger. 2006. Archaeology, language, and the African past. Lanham, MD: Altamira Press.

Bloomeld, L. 1933. Language. London: Allen and Unwin.

Bostoen, Koen. 2007. Pots, words and the Bantu problem: On lexical reconstruction and early African history. Journal of African History, 48: 173-99.

Botne, Robert. 2008. A Chindali and English dictionary with an Index to Proto-Bantu roots. Philadelphia: American Philosophical Society.

De Maret, Pierre \& Nsuka François. 1977. History of Bantu metallurgy: Some linguistics aspects. History in Africa 4: 4365.

Felberg, Knut. 1996. Nyakyusa-English-Swahili and EnglishNyakyusa Dictionary. Dar es Salaam: Mkuki na Nyota Publishers.

Gewald, Jan-Bart. 2005. Colonial warfare: Hehe and World War One, the wars besides Maji Maji in south-western Tanzania. ASC Working Paper No. 63. African Studies Centre, Leiden, the Netherlands.

Haspelmath, Martin. 2009. Lexical borrowing: Concepts and issues. In Loanwords in the world's languages: A comparative handbook, ed. Martin Haspelmath \& Uri Tadmor, 35-54. Berlin: Mouton de Gruyter.

Kahigi, Kulikoyela K. 2008. Kahe-Swahili-English and EnglishKahe-Swahili Lexicon. Dar es Salaam, University of Dar es Salaam, LOT Publications.

LOT (Language of Tanzania). 2009. Atlasi ya lughaza Tanzania. Dar es Salaam: University of Dar es Salaam.

Lusekelo, Amani. forthcoming. Education-induced borrowing in Tanzania: Penetration of Swahili nouns into Maa (Maasai) and Hadzane (Hadzabe), Language Matters, 48. 
. 2014. 'Similar' language contact but 'different' language change: Historical lessons from loanwords in Tanzanian Bantu communities. Journal of Education, Humanities and Sciences, vol. 3(1\&2): 92-111.

. 2013. Swahili loanwords nativisations in the languages of

Tanzania. HURIA Journal of the Open University of

Tanzania 14: 151-162.

Mapunda, Gastor \& Tove Rosendal. 2015. Borrowing in Tanzanian Ngoni lexicon: Some semantic trends in a language contact situation. Language Matters: Studies in the Languages of Africa 46(2): 180-194.

Mattsson, Jenny. 2009. Study of rural housing in Mamba district Kilimanjaro, Tanzania. Research Report, Jönköping University.

Mosha, Livin H. 2011. Imposition of architectural and spatial planning concepts into local dwelling culture. Prime Journal of Business Administration and Management, vol. 2(6): 596603.

Mreta, Abel. 2008. Simbiti-Swahili-English and English-SimbitiSwahili lexicon. Dar es Salaam: Language of Tanzania Project.

Mwakyusa, Ambwene T. H. 2006. Traditional and contemporary building styles used in Tanzania and to developmodels for current needs. Doctoral thesis, St. Clements University of British West Indies.

Mwalonya, Joseph, Alison Nicolle, Steve Nicolle \& Juma Zimbu. 2004. Mgombato: Digo-English-Swahili Dictionary. Kwale: Digo Language and Literacy Project.

Nizarudin, Norhanis D., Mohd. R. M. Hussain \& Izawati Tukiman. 2011. The Green Building Index (GBI): An innovation in landscape architecture. In $1^{\text {st }}$ IFLA Asia Pacific Region 
Symposium on Landscape Architecture Education (SOLARE 2011), 30 March - 2 April 2011, Perbadanan Putrajaya Complex, Putrajaya.

Nurse, Derek. 1997. The contributions of linguistics to the study of history in Africa. Journal of African History, 38: 359-91.

— 1988. The diachronic background to the language communities of SW Tanzania. SUGIA 9: 15-116.

. 1979. Classification of the Chaga dialects: Language and history on Kilimanjaro, the Taita Hills and the Pare Mountains. Hamburg: Helmut Buske Verlag.

Nurse, Derek \& Henry R. T. Muzale. 1999. Tense and aspect in Great Lakes Bantu languages. In Bantu historical linguistics: theoretical and empirical perspectives, pp. 517-44. Ed. JeanMarie Hombert \& Larry Michael Hyman. Stanford: CSLI (Center for the Study of Language and Information) Publications.

Petzell, Malin. 2008. The Kagulu language of Tanzania: grammar, text and vocabulary. Cologne: Ruediger Koeppe Verlag.

Rubanza, Yunus. 2008. Zinza-Swahili-English and English-Zinza-

Swahili Lexicon. Dar es Salaam, University of Dar es

Salaam, LOT Publications.

Rugemalira, Josephat M. 2013. Makonde-English-Swahili

Dictionary (with English and Swahili Glosses). Dar es

Salaam: Language of Tanzania Project.

Rugemalira, Josephat M. 2009. Cigogo-Swahili-English Dictionary. Dar es Salaam: Language of Tanzania (LOT) Project.

Rugemalira, Josephat M. 2002. Runyambo-Kiswahili-English Lexicon. Dar es Salaam: Language of Tanzania Project. 
Sebonde, Rafiki. Y. 2014. Code-switching or lexical borrowing:

Numerals in Chasu language of rural Tanzania. Journal of Arts and Humanities 3(3): 67-76.

Sewangi, Seleman S. 2008. Ikiizu-Swahili-English and English-

Ikiizu-Swahili Lexicon. Dar es Salaam, University of Dar es

Salaam, LOT Publications.

Ten Raa, Eric. 1970. The couth and the uncouth: Ethnic, social, and linguistic divisions among the Sandawe of Central Tanzania. Anthropos, 65(1/2): 127-153.

Traugott, Eizabeth C. \& Richard B. Dasher. 2002. Regularity in semantic change. Cambridge: Cambridge University Press.

TUKI (Taasisi ya Uchunguzi wa Kiswahili). 2001. Kamusi ya Swahili-Kiingereza. Dar es Salaam: Institute of Swahili Research.

Walsh, Martin T. \& Imani N. Swilla. 2000. Linguistics in the corridor: A review of the research on the Bantu languages of South-West Tanzania, North-east Zambia and North Malawi. Paper presented to the international colloquium on Kiswahili in 2000, Institute of Kiswahili Research, University of Dar es Salaam, 20-23 March 2000.

Yoneda, Nebuko. 2010. "Swahilization" of ethnic languages in Tanzania: The case of Matengo. African Study Monographs 31(3): 139-148. 